\title{
From OAU to AU: New Wine in Old Bottles?
}

Armstrong M.Adejo*

If we are to remain free, if we are to enjoy the full benefits of Africa's rich resources, we must unite to plan our total defence and the full expectation of our national and human means, in the full interest of all our people. To go it alone will limit our horizons, curtail our expectations and thereafter our liberty. - Kwame Nkrumah.

\section{Introduction}

The coming to fruition of the African Union at the seminal assembly of African states, held in July 2002 in South Africa, 'closed the shop' on the Organization of African Unity which had been in existence since May 1963. Incidentally, this momentous development came a little over a century since the first ever Pan-African Conference was held in London. This development has generated much excitement among African analysts, albeit with some cautious predispositions regarding the future of the new Union. These reservations derive from the problem of who controls the development agenda of African states, which has been a matter for concern over the decades. At independence, nearly all the states of Africa and their leaders were in no position to undertake meaningful progress because they were too engrossed in the struggle for survival and the need to cope with the many problems threatening their countries and their power.

However, against the realities of the international division of labour many leaders of African states were quite aware that on their own individual countries would not make any reasonable economic headway in a world that discriminates overtly against them. Consequently, since 1960 many attempts have been made to channel African aspirations towards a greater political unity based on a programme of freedom, equity, and justice. Against many

\footnotetext{
* Department of History, Benue State University, Makurdi, Nigeria.
} 
odds, the Organization of African Unity (OAU) emerged with high hopes of tackling Africa's problems. The search for progress in a competitive, progressive world indicated clearly to some African leaders that the course of the OAU would be tortuous and the search for development strategies would multiply. Thereafter, the continent was subjected to waves of regional integration initiatives. Bearing in mind the challenges of globalisation, the conviction on the part of several analysts was that the only choice for Africa's salvation lay in continental union. The emergence of the African Union thus came out of a litany of initiatives dating over decades. It is this struggle that is the subject of this paper. The paper discusses four major areas as related to the roots of the African Union: a brief theoretical framework which looks at the lure of regionalism; the emergence of OAU itself, the road to the African Union; and the challenges ahead.

\section{The Lure of Regionalism: A Theoretical Perspective}

At independence, the economies of African states were structurally disarticulated because they had been developed as aggregations of enclaves, each linked to the metropolitan economy but not necessarily to one another. As Claude Ake noted, even though individual states of Africa seemed content to surrender their development agenda to external development agencies, they still groped collectively towards a vision of how to proceed. ${ }^{1}$ It was contended that such collaborative efforts would serve as building blocks of a future African Economic Community or African Union. Consequently, the lure of regionalism has had a profound effect on the foreign policies of African states.

However, much confusion often arises as to the application of the terms 'regionalism' or 'sub-regionalism' in describing integration efforts in Africa. Many of the attempts are informed by the experiences of North America and Europe. But the argument could be put that many regional cooperation efforts were 'home grown', an organic development within specific historic, political, economic, regional and global contexts. ${ }^{2}$ The arguments advanced by the political elites in favour of regional cooperation, as Anthoni van Nieuwkerk writes, were simple and elegant. First, regional efforts would strengthen the capacity of countries to manage 
relations with powerful external actors and could facilitate the expansion of markets that would aid industrialisation. Second, faith in regional cooperation was strengthened by the post-Cold War academic 'discovery' of a new form of regionalism comprising a multidimensional form of integration that included economic, political, social, and cultural aspects. ${ }^{3}$ The first argument favoured the emergence of the OAU since the states of Africa were not committed to any formal regionalism which would be the outcome of state policies involving the transfer of national state powers to a supra-natural body or a hegemonic state. This cautious disposition resulted in half measures even with regard to the regional and subregional groupings which emerged. Consequently, the impact of inter-state relations remained important but instead of integration, the experience in inter-governmental cooperation seemed more successful, arising from the desire to coordinate sectoral policies.

Thus, the first generation of African integration arrangements focused principally on trade promotion through trade liberalisation schemes based on the creation of free trade areas. This strategy, as the Nigerian President, Olusegun Obasanjo has revealed, was to overcome three fundamental development constraints characteristic of African economies: namely the relative small-sized economies, the lack of structural complementarity as manifested in the narrow set of similar low-value goods, and the dependence on import of intermediate and capital goods. ${ }^{4}$ A plethora of regional integration institution which came into existence included:

- The Customs and Economic Union of Central Africa (UDEAC 1964), later the Central African Economic and Monetary Community (CEMAC).

- The East African Community (EAC 1967-1977), now the East African Cooperation.

- The West African Economic Community (CEACO, 1972).

- The Economic Community of West African States (ECOWAS, 1975).

- The West African Economic and Monetary Union (UEMOA, 1990).

- The Preferential Trade Area (PTA 1980) now the Common Market for East and Southern Africa (COMESA, 1999). 
- The Southern African Development Coordinating Conference (SADCC, 1980) now Southern African Development Community (SADC 1992).

- The Union of Maghreb Arab States (UMA, 1988).5

It is significant to indicate that in spite of the proliferation of regional integration institution on the African continent over the decades, a dispassionate assessment of the impact of Africa's efforts at regional economic cooperation and integration between the 1960s and 1990s suggests that the expected benefits have eluded the continent. It is not difficult to establish the reasons for these unprofitable results. At independence, it was assumed that the international order would significantly help to alter the African condition. African leaders put great efforts into development through internationalism, thinking perhaps that this would be a useful way of getting resources from the West while diversifying their dependence enough to find some space for manoeuvre. This approach was tested in the demand for a new world order, which accomplished nothing - if anything it increased the frustration of the impoverished nation-states of Africa.

As has already been pointed out, African states were structurally disarticulated, each linked to the metropolitan economy but not necessarily to one another. At such a critical conjuncture, the dependence development approach was a politically driven decision and with the dearth of native economists and planners, there was a reliance on expatriates which in turn caused and reproduced neo-colonial notions of development. However, complacency of the political leaders in relying on a foreign developmental paradigm came under pressure. The need to develop endogenous plans led to what Claude Ake usually refers to as the emerging of a 'confusing agenda'. ${ }^{7}$ But as Ake himself was quick to observe, although individual African states seemed content to surrender their development agenda to external development agencies, they did grope collectively towards a vision of how to proceed, especially with the establishment of the OAU.

One such vision was the Lagos Plan of Action which was the implementation of the Monrovia Strategy for the Economic Development of Africa (adopted in July 1979). The Lagos Plan of Action (LPA) was the most comprehensive and systematic statement 
of the vision of Africa's leaders on the development of the continent. It stemmed from the effect of unfulfilled promises of global development strategies which had been felt more sharply in Africa than elsewhere. To the irritation of Africa's foreign patrons, the LPA agreed that Africa's economic problems were partly caused by Africa's dependence and opening to exploitation, hence the necessity for self reliance. The Bretton Woods institutions and the West would not accept the approach of the Lagos Plan, although they refrained from opposing it openly. Unfortunately, African leaders began to retreat, discovering that they were too weak and too dependent, and so they began to reform their economy along the lines suggested by the Bretton Woods institutions. Most significant was the adoption of the devastating SAP. For progressive action, one could posit this devastation, on a scale that African states historically faced, had its usefulness. This is because marginalisation, often decried, is what Africa radically needs for it to evolve an endogenous development agenda. It is on these grounds that the development of relatively cohesive and integrated regional groupings has concerned some writers whose focus has been upon the maintenance of world order and stability.

During the 1960s and in the wake of what appeared to be widespread enthusiasm for developing regional groups and schemes to promote economic integration, regions in international politics began to be comprehensively defined. Some viewed regionalism as 'a limited number of states linked by a geographical relationship and by a degree of mutual independence'. ${ }^{9}$ This must not be taken exclusively as the dominant paradigm for regionalism, because it required not only geographical proximity and increased economic interdependence for its promotion but other factors that are significant in underpinning potential development of regional problem-solving processes. These include historical experience, power and wealth distribution within and outside the grouping, social and ethnic tradition and ideological or political preferences. ${ }^{10}$

Regionalism, according to Hurrell, can be broken up into specific or concrete types to identify important variations in the concept, and such variations could be explained according to the level of growth in socio-economic interdependence; according to the extent to which shared values and cultural traditions persist; according to 
the extent to which formal institutional arrangements are sought; and the extent to which a regional grouping displays a cohesive identity and external presence. ${ }^{11}$ Some may be solely concerned with maximising economic welfare and gains from international trade and investment, while others ate concerned with defence and security or the protection of social and cultural traditions. Regionalism is thus conceived as a body of goals laid down for the regional project. It is the body of visions, values, and concrete objectives that supervise the processes of the interaction between state and market aimed at providing and maintaining national and regional security in a broad sense. In this conception geography is not by necessarily an objective criterion. It is, according to Morten Boas, a social construct. ${ }^{12}$

It is also important to point out that the intellectual construct with which the conception of regionalism has been theoretically associated is classical functionalism, which is in contrast to the idea of world federation. Functionalism, of which regional cooperation agreements bear the trade mark, is directed at building "peace by pieces' through transnational organisations which emphasise the 'sharing of sovereignty' instead of its surrender, and an evolutionary strategy for building cooperative ties among states. ${ }^{13}$ Kegley and Wittkopt state that the functionalist plan recommends that less difficult tasks be tackled first, assuming in the main that the successful mastering of one problem will encourage the tackling of other problems collaboratively. ${ }^{14}$ Consequently, if the process continues unabated, the bonds among countries will multiply since no government would oppose the web of functional organisations that provides such clear-cut benefits to its citizens.

By the middle of the $20^{\text {th }}$ century, the functionalists' theory began to be attacked as analysts contended that functionalism was an idea whose time had passed. In its peace emerged neo-functionalism which sought to address directly the political factors that obtrusively dominate the process of merging formerly independent states ${ }^{15}$ Arising from this, the concept of integration is rather more difficult to define. It can be understood as a condition or as a process; as a description of a system with its elements already in existence, or as an explanation of how a political system is sustained and developed in a particular direction. A useful view, as posited by Baylis and Smith, sees integration: 
As the creation and maintenance of intense and diversified patterns of interaction among previously autonomous limits. These patterns may be partly economic, social, and political in character. ${ }^{16}$

Integration could be a kind of formal process which involves conscious political decision, a process designed to deepen interrelatedness and exchanges between a group of countries by way of economic integration or political integration, which can involve not merely the formation of institutional mechanism and decisionmaking procedures but also the development of shared values and expectations, the peaceful resolution of disputes, and socio-political cohesiveness. Integration could also be in the form of informal processes involving economic, social, and cultural flows.

The study of regionalism and integration lies in the problem of how conflict can be avoided, and how cooperation and stability can be maintained. The development of regional cooperation and structures is often explained as a utilitarian and state-driven process enabling states to reconcile competing demands in the face of global political and economic challenges. However, neo-realist-neo-liberal debate in international relations, as Baylis and Smith posit, is divided on whether regional cooperation and grouping are effective and reliable instruments to maintain order and peace. ${ }^{17}$ This debate, as the authors note, encourages analysts to think about important characteristics of cooperation such as reciprocity, i.e. the expectation of mutually regarding behaviour and the distribution of gains from cooperation. For instance, countries in Latin America have consistently pursued forms of regional economic integration since 1950. South America is also characterised by a number of regional integration schemes and cooperation between the richer developing countries. In any case, this enthusiastic process has had patchy success as political difficulties associated with different government philosophies, territorial disputes and infrastructural weakness have combined to dilute the progress made.

In South East Asia, political and economic cooperation within the Association of South East Asian nations (ASEAN) since 1967 has made for invaluable cooperation. Since 1992, there have been progressive efforts toward regional economic integration with an agreement to develop an ASEAN Free Trade Area and the 
establishment of Asia-Pacific Economic Cooperation as a wider forum. Significant economic differences do characterise the region's economy but it is also an important factor in the future development of intra-regional cooperation.

The European regional integration approach has been more fundamental and has influenced almost all regional experiences. During the post-1945 period Western Europe gradually constituted itself as a highly integrated and cohesive grouping of economies and peoples. It should be stated, however, that the historical and political changes that shaped and continue to shape European experience may not exist in other regional groupings. Consequently, it will be inappropriate to readily transpose the European expectations to the study of other regional groupings. The African experience readily comes to mind in this regard. Most African states have continued to confront colonial legacies of arbitrary territorial boundaries, weak and inefficient state structures, profound social and cultural cleavages and protracted conflicts.

In all the regional integration efforts, the central influence of the state has remained decisive. Some analysts contend that global changes call into question the usefulness of the nation-state itself because it does not seem to be losing control and integrity. Its overbearing force and the emotion that surrounds national matters of security, economic and political development, hinder effective cooperation. As the argument holds, the nation state appears to be the wrong sort of unit to handle the new circumstances of global change. In this respect, neo-realist theory helps to explain why the proposals for international cooperation and change often seem dim. Inter-governmental organisations are products of the interest of the nation-state and in their operation, fear is endemic to the system as long as states wish to survive, being wary of the threat posed by others. The states are sensitive to their relative position in the distribution of power, and to the uncertainty about each others' future intentions.

Consequently, the argument is that when the states dominate international organisations, like the OAU, the prospects for international cooperation decline because states typically resist any actions that could compromise their own interests. However, neo-liberal theorising holds to the perspective which maintains that 
cooperation among states, even powerful ones, is possible and that international organisations can help produce it. One example is the European Union, which combines two important features: a 'supranational entity' and a 'pooled sovereignty'. The EU has the power to make some decisions binding on its members without being subject to their individual approval, which in a sense qualifies it as a supranational entity because it goes beyond the state, mirroring the vision of its founding fathers. Secondly, the EU, although it incorporates some supra-national elements, constitutes a pooled sovereignty because states remain paramount in its institutional structures and decision-making procedures. Sovereignty is shared in this process.

In the African situation, it would not be inappropriate to argue that the study of regional organisations should put behind it the blueprints based on the European experience and commence probing into new unknown ground. Accordingly, Morten Boas states that

we will have to set aside the universalistic approach to regionalization and accept that regional organization is not developed within the framework of just one rationality, but in several localized rationalities. ${ }^{18}$

\section{The OAU and Africa's Development}

Pan-Africanism has a rich history dating back to the $18^{\text {th }}$ century, coming from the new world rather than Africa itself. Prince Hall, a black cleric in Boston, campaigned unsuccessfully in 1787 for help from the state Assembly in returning poor blacks to Africa. He was followed by Bishop McNeil Turner who established the American colonialism society.

However, it was the naked scramble for Africa, after the 1884 Congress in Berlin, that gave new urgency to the Pan-African response. In 1886, George Charles, President of the African Emigration Association, declared to the United States Congress that his organisation planned to establish a United States of Africa. Consequently, Pan-Africanists convened their own Congress in Chicago in 1893. In 1900, the first Pan-African Conference was convened in London by Henry Sylvester Williams, a lawyer from Trinidad. In the first half of the $20^{\text {th }}$ century, the twin giants of Pan- 
African Movement were Marcus Garvey and W.E.D. Dubois. Dubois organised another Pan-African Congress in Paris in 1919 to coincide with the Versailles Peace Conference, hoping to persuade the world leaders that the principle of self-determination should be applied to Africa as well. ${ }^{19}$

In the 1920s Dubois organised three more Pan-African Congresses, but the main impetus of Pan-Africanism by the 1930s in America was cultural. In 1945, the fifth Pan-African Congress was held under Dubois. The most fundamental change at that time was that the torch of Pan-Africanism had in reality passed on to new generation of Pan-Africanists from the continent of Africa itself - to men like Kwame Nkrumah and Jomo Kenyatta. Nkrumah became the voice and organising force of Pan-Africanism. In the 1940s and 1950s he promoted the idea of an independent West African federation, as first step towards a United States of Africa.

When Kwame Nkrumah led Ghana to independence in 1957, he inspired Africans resisting colonialism and seeking freedom all over the continent. His firm conviction was that national independence was not enough and he spent much of his energy pursuing the possibility of a united Africa. In April 1958, he organised the first Conference of Independent African States - attended by Ethiopia, Egypt, Ghana, Liberia, Libya, Morocco, Tunisia, and Sudan. The Conference declared a policy of non-alignment in world affairs and decided to coordinate African policies on international political questions.

The second conference of independent African States was attended by 13 countries and they included the Provisional Government of Algeria, Ethiopia, Ghana, Guinea, Libya, Morocco, Nigeria, Somalia, Sudan Tunisia, UAR, and Cameroon. Participants expressed deepseated ideological differences regarding the form African Unity was to take. ${ }^{20}$ However, despite the basic disagreements and numerous inter-state squabbles, independent African states maintained a façade of unity until the last half of 1960 when a number of unrelated events led to the formation of competing political alliances. Some of the most important developments included Nigeria's attainment of independence, which challenged Ghana's claim to leadership; Morocco's quarrel with Tunisia over Mauritania's right to exist as a separate sovereignty state; the accession of thirteen francophone 
African states to independence and their being accused of failing to oppose France's policy on Algeria and sending African troops to combat FLN in Algeria, support for western policies, the signing of defence pacts with France and their opposition to Patrice Lumumba in the Congo. ${ }^{21}$ The most fundamental development which widened the emerging rift among African states was the Congo problem and the rise of competing alliances.

In October 1960 in Abidjan, Ivory Coast a number of Francophone African states held a conference (although Guinea, Togo, and Mali were absent). The conference tried to formulate direct negotiation between Algeria and France and recognised the right of Mauritania to full independence. In 1961 they established the Africa and Malagasy Union (UAM).

The formation of the UAM led to the establishment of a radical alliance at Casablanca in January 1961 where Ghana, Guinea and Mali sought to escape isolation in the face of the moderate alliance of Francophone states. It held a conference, supported Patrice Lumumba, and enunciated its radical proposals for African unity in a 'Casablanca Charter'. ${ }^{22}$ As a countervailing force the moderate alliance was enlarged at a meeting held in Monrovia in May 1961. It now included Ethiopia, Liberia, Libya, Nigeria, Sierra Leone, Somalia, Togo, and 12 UAM members. By the time of the summit Conference in Addis Ababa in 1963, where the Organisation of African Unity (OAU) was created, the Casablanca Group had become relatively weak, while the moderates were clearly in the majority to push their agenda. A preparatory Conference of African Foreign states held on May 15-23 was charged with the formulation of plans for the establishment of the OAU. A Committee constituted for this purpose studied a variety of proposals including the Casablanca Charter, the Lagos Charter, Nkrumah's plan and a draft charter prepared by the Ethiopian government, the host country. The Committee encountered great difficulty in effecting a compromise because the Casablanca charter reflected the ideal of political union while the Monrovia group advocated a more conservative policy.

While Nkrumah could obtain support for his radical position from the Casablanca Group, there was strong opposition to the idea of an African Union from the Monrovia group, which included the Francophone bloc. This group, led by imperialist propaganda, 
insinuated that the radical Casablanca group was communistinspired. Unfortunately, the fear of opposition in various African countries had helped the capitalists to play up the crises of subversion as the instruments of the radical group. The division placed serious obstacles on the path of African cooperation. However, the heads of African states were determined to approve a charter, which became a compromise charter signed on May 25, 1963. At this time hardcore radical states were Algeria, Ghana, Mali, and UAR. Thereafter, it was clear that the composition of the ideological bloc was not stable and some of them managed to maintain two foreign policy positions simultaneously.

Interestingly, the purposes and objectives of the OAU, as stated in Article 11 of the Charter, included the following:

- To promote the unity and solidarity of the African states;

- To coordinate and intensify their cooperation and efforts to achieve better life for the people of Africa;

- To defend their sovereignty, their territorial integrity and independence;

- To eradicate all forms of colonialism from Africa and to promote international cooperation, having due regards to the Charter of the UNO and the Universal Declaration of Human Rights.

To this end, the member states agreed to coordinate and harmonise their general policies especially in the following fields: political and diplomatic cooperation, economic cooperation including transport and communication, health, sanitation and nutritional cooperation; scientific and technological cooperation, and defence and security cooperation. Among the cardinal principles of the OAU, an aspect which has allowed for uncomplimentary remarks on the OAU in the last four decades, were the issues of non-interference in the internal affairs of member states (which is most un-African) and the inherited colonial borders remaining sacrosanct.

In the OAU, as analysts observe, several groups of states sharing similar values on a wide range of issues interacted with one another along the lines of a classical multipolar balance-of-power type of international system. Equally, the organisation could be likened to the post-Napoleonic concert of Europe in some respects as it worked for the preservation of existing political systems and borders in Africa 
either by direct action or inaction. At independence the leaders were in no position to undertake serious development initiatives because they were too engrossed in the struggle for survival and the need to cope with the many problems threatening their countries and their power.

The OAU became a painfully ineffectual regional body, too often presided over by dictators who made a mockery of its Charter's concern for human rights and social justice. National leaders stoutly defended the colonial borders they had inherited and, as Chris Brazier puts it, 'there was a fear if these borders were dissolved, all hell might let loose'. ${ }^{23}$ As individual nation-states within artificial borders they could too easily be played off against each other by the imperialists in a post-colonial version of divide and rule. ${ }^{24}$ That was exactly what unfolded and the idea of a united Africa then became progressively consigned to the past with the notion of PanAfricanism anathema to some leaders. Sustaining the OAU, even on the basis of the regular budget, became very difficult. Problems plaguing the OAU included:

- The secessionist wars like the Biafran episode;

- The fascist rule of dictators like Idi Amin;

- The Rwanda problem where millions of people died;

- The Burundi periodic killings since 1988;

- The internecine civil wars in Angola, Chad, Sudan;

- The war between Ethiopia and Eritrea;

- The disintegration in Liberia, Sierra Leone, Somalia;

- Morocco's unending hold on western Sahara;

- The scourge of HIV/Aids;

- The poverty and debt burden;

- The Nigeria-Cameroon palaver over Bakassi.

The political, economic and social environment in which African states found themselves since 1960 has not altered much in a favourable way and Africa's current problems seem to resist every attempt at resolution.

The frustration of African leaders in the OAU was clearly recognised in the need for progress in Cairo Declaration at the $29^{\text {th }}$ Summit of Heads of State and Government of OAU in Cairo which states, among other things, that: 
Despite the fundamental changes that have taken place in the post independence era and more particularly since the end of the Cold War, there is still the need for establishing a close link between development, democracy, security and stability in the years ahead as the most ideal formula for fulfilling the legitimate aspirations of the peoples of Africa to a decent life, progress and social justice. This formula will enable us to solve gradually the acute socio-economic and political problems facing the African continent. It will also serve as a proper framework for the preservation of the diverse nature of our nations and societies and further enhancement of the fraternal ties that exist between our states. ${ }^{25}$

These words sounded no different from innumerable similar declarations of intent emitting from the OAU in the past.

\section{The Emergence of the African Union and the Challenges facing it}

Novelty, they say, has its attractions and, as Cameroon Duodu sarcastically observes, in News-Africa of July 29, 2002, 'who would blame an organization with a record of poor performance if it wishes to take a leaf out of the book of a corporate boardroom and "rebrand" itself?' Kwame Nkrumah had set the stage a long time ago but the other African actors were acting out other scripts which they could not discard. Nkrumah had been clear in his own mind:

We can't afford to place our needs, our development, our security, to the gait of camels and donkeys. We cannot afford not to cut down the overgrown bush of outmoded attitudes that obstructs our path to the modern open road of the widest and earlier achievement of economic independence and the raising up of the lives of our people to the highest level. ${ }^{26}$

The flame of unity and freedom lit in the sixties has continued to glow, though dimly, to illuminate the path of the transition from the OAU to the African Union (AU). The AU is not a child of an impetuous inspiration but the offspring of a gradual but dedicated progression towards ideals and commitments. The continent has remained in dire need of solutions to its critical problems and it is this very condition that propels the need for change and progress. When, in the $1990 \mathrm{~s}$, the 
notion of a Pan-African Union was born again, it was the liberation of South Africa from apartheid that helped it back to life. Equally, there is the argument that the main influence propelling Africans towards greater economic and political unity is globalisation. Faced with a trading system which insists on transnational capital having carte blanche, Africans became increasingly aware that they would have to stand together if they were to defend or advance their own cause. But even as they favoured unity in principle, they could not necessarily agree on how closely united they should be and what forms their unity should take.

Several years ago the OAU Summit had set up a 14-member committee to review its charter. By 1996 when the Yaounde Declaration was issued, the Charter Review Committee had held six sessions and had submitted, on an annual basis, reports to the OAU summit. As Jackie Cilliers notes, not dissimilar to the impasse within which the UN finds itself, the review of the OAU Charter remained the captive of the competing national interests of a number of member states. ${ }^{27}$ However, for a number of important countries, such as South Africa, the initiative towards the establishment of the AU provided a way out of this impasse.

A major problem, indicative of the ideological divide of the 1960s, was the vision of a single federal African states that inspired leaders like Moammar Gaddafi, a vision which many of the states did not share but which they were hesitant of criticizing. The Libyan initiative, it was interpreted, was intended to enable the North African leader to break out of the prolonged diplomatic isolation brought about by its poor relations with the US, the UK and some of the Arab States. Notwithstanding the misgivings, the declaration adopted by the $4^{\text {th }}$ Extra-ordinary Summit of the OAU held in Sirte, Libya, in September 1999 set the fast track to the Constitutive Act of the AU that emerged. In July 2000, African Heads of state met in Lomé, Togo for the 36th Ordinary Summit of the OAU. At the end of that Summit they came out with a Draft Treaty for an African Union which would replace the OAU. Incidentally, that came a hundred years after the first-ever Pan-African Conference was held in London.

The OAU Lusaka Summit meeting of July 2001 mandated the Secretary-General to proceed, in consultation with member states, 
with a process to work out the rules of procedure to launch the key structures within the AU; such as the Assembly of heads of states and government; the Executive Council of Foreign Ministers, the Commission (including its structures, functions and powers), and the Permanent Representatives Committee of Ambassadors. The Lusaka Summit also agreed to incorporate the mechanism for conflict prevention, management and resolution as an organ of the AU. After a review of its structure, procedures and working method in a typically uncertain manner, the first draft text provided for the AU to co-exist with the OAU and AEC rather than serving the purpose of rationalisation and consolidation.

The seminal assembly of the African Union held in July 2002 in South Africa 'closed the shop' on the OAU which had been in existence since 1963. Much hope was raised by this development as manifested in the statement of the Nigerian Foreign Minister, Sule Lamido:

Arising from the realization in today's world order, we Africans are essentially on our own, the leaders had to re-think. We have to look inwards to try to create a stronger, more effective process of continental interaction, something more integrative, merging our economies, markets, and capacity. We have to bring our potentials so that our partners will be forced to engage us. ${ }^{28}$

Such moving statements have not been lacking in Africa but the $\mathrm{AU}$, like OAU, is an inter-governmental organisation and the pace of change is therefore still likely to be determined by what cynics refer to as 'lowest common denominator politics'. ${ }^{29}$ The Constitutive Act of the AU envisages the establishment of a supranational type of executive body that can promote integration and sustainable human development more effectively than the OAU. The Act has the following bodies as principal organs:

- The Assembly of the Union;

- The Executive Council;

- The Pan-African Parliament;

- The Court of Justice;

- The Commission;

- The Permanent Representatives Committee;

- The Special Technical Committees; 
- The Economic, Social and Cultural Council;

- The Financial Institutions.

Among the AU's major objectives, as stated in Article 3 of the Act, are:

- Active greater unity and solidarity between African countries and the peoples of Africa;

- Acceleration of the political and socio-economic integration of the continent;

- A common market and economic community;

- International cooperation, taking dual account of the charter of the UN and the Universal Declaration of Human Rights;

- A common defence policy for collective security.

Keeping in mind the challenges of globalisation and marginalisation there was a consensus, even if only for public consumption, that the aim of the Union would be to consolidate the gains made by the OAU in 37 years and to advance from there to chart a new dynamic vision of collective continental action and cohesion for Africa. The big question, however, is, will the re-launch or rebranding of the OAU achieve the desired objectives? Can the AU stop the "yawning and the tightening of the stomach muscles that used to accompany the mention of the name of the OAU"? ${ }^{30}$ Would a United Africa benefit the ordinary people and can African leaders sustain the organisation through a corporate agenda?

Critics have been quick to dismiss the Constitutive Act as utopian, while some believe that the treaty does not present a new agenda for Africa, as the whole thing appears to be only a declaration of intention which does not respond to the realities and aspirations of Africans. Although reinforcing stereotypes of 'backwardness' and 'hopelessness' is not conducive to finding solutions to any of Africa's problems, old habits die hard. Though the post-Cold War ideological schisms are eroded, the contentious matters stemming from the colonial background, which hamstrung the OAU in several instances, persist. A union that must last cannot be driven by the distrust which prevails in some circles of collective effort in Africa. The state-centric approach to international affairs leads states to think of sovereignty from an exclusive angle. Many leaders do not 
share the vision of a single Federal African state.

Under the terms of the Constitutive Act of the AU, Article 4 lists 16 principles which contain an ambitious wish list, including, for example, the establishment of a common defence policy and the "right of the Union to intervene in a member state pursuant to a decision of the Assembly of the Union in respect of grave circumstances, namely war crimes, genocide and crimes against humanity". As Michael Mulikita rightly observes, the Act makes no reference to the UNSC, which is the primary instrument for dealing with the type of emergencies referred to in Article 4(h) of the Act. ${ }^{31}$ More worrisome and in the classic manner of state-centric organisations, Article 4(g) effectively nullifies Article 4(h) by affirming "non-interference by any member state in the internal affairs of another". Hence, as Mulikita concludes, under the non-interference clause, a regime guilty of the type of gross human rights violations outlined in Article 3 (on the Universal Declaration of Human Rights and the promotion and protection of human and people's rights in accordance with the African Charter on Human and People Rights) and Article 4(h) can legally obstruct Union intervention. This confirms the old habits, the old fears and the old traits since the 1960s. The Act does not provide for the tools or mechanism with which to implement, monitor or advance these lofty ideals. It is recalled that in the OAU Charter, Article 3(2) on non-interference in the internal affairs of member states led to serious drawbacks and had negative implications for the activities of the organisation for several decades. In this the period, ruthless, corrupt and unaccountable leaders emerged across the continent, without African states or leaders confronting them. Along with other factors, it led OAU to degenerate into what the Kenyan statesman, Oginga Odinga, called "a Trade Union of African Heads of State". 32

In the same vein, Article 30 states that governments that come to power in future through unconstitutional means will not be allowed to participate in the activities of the Union. Jackie Cilliers believes that the Act does not incorporate extensive principles for democratic governance, the definition of unconstitutional changes, or the measures that the AU would take in response to such developments. ${ }^{33}$

These apparent contradictions, admittedly, provide an example of the ambivalent attitude of African states towards the sensitive issue 
of national sovereignty. It strengthens the impression that the AU amounts to merely giving the OAU a 'fresh coat of paint' without the inner structures undergoing any renovations. ${ }^{34}$ This paper, without lapsing into unprofitable pessimism, notes that the AU project is going to be a much more expensive undertaking than the regular amount of \$31 million annual budget of the OAU. Quite clearly, much thought needs to be devoted to how the union will be funded, especially the Pan-African Parliament. The doubts emerge against the background of the fact that by mid 2000, only 17 of the 53 member states of the OAU were up to date in the settlement of their financial obligations to the regular budget. ${ }^{35}$ The question is how will the additional obligations be met, against the background of the near permanent poor showing of African economies.

The establishment of a union as contained in the Constitutive Act presupposes a high degree of social and political integration of member states. It remains unclear whether a union modelled along the example of European integration can be successfully established in Africa. This is all the more problematic in the sense that intra-African trade, notwithstanding the existence of sub-regional economic arrangements as ECOWAS, SADC, and COMESA, has persistently remained below the 5 percent mark calculated as a fraction of the continent's total external trade. ${ }^{36}$ The overlapping membership of several regional grouping with duplicating mandates and structures leading to inadequate financing of the integration process, poses a serious threat to continental union. Ironically, African leaders refer to their sub-regional efforts regarding security arrangements, but they are not ready openly to chastise their colleagues for undemocratic tendencies in their sub-regions.

Some of the noticeable habits of the African leaders which have not altered dramatically over the decades are obstacles to any genuine union on the continent. These include a penchant for luxury items like expensive official vehicles, presidential jets and the expending of inordinate amounts on running public offices, foreign travel and diplomatic representation which cannot be sustained, instead of engaging in pooling or coordinating representation; military spending in excess of two percent of the GNP (any success achieved in reducing military spending translates into an expansion of public domestic savings); corruption which is widely recognised as a 
serious obstacle to development; and ethnic and communal conflicts fuelled by elite struggle and the asphyxiating debt gap.

Finally, the AU is an ambitious undertaking but despite the change in name, many of the institutions that have been created as part of the OAU and the African Economic Community will continue unchanged for the foreseeable future. However, in spite of the these identifiable features, it is necessary to provide clarity on whether the Union is a replacement or a continuation of the OAU and whether the Union aims at both economic and political integration. The overwhelming competition instituted by globalisation must be openly noted because globalisation in its current form is the biggest threat to African independence, sovereignty and therefore to its development. Globalisation is said to be a magnified integration which threatens all.

One could be driven by the optimistic variety of patriotism to believe that the Union can be made to work for the African people at large. However, at a more critical level, if is difficult to believe that adequate space will be made for what is widely referred to as African civil society, especially if that civil society seeks to make use of the aspirations of the AU to offer criticisms of rulers which are illegal to voice at the national level. Many are sceptical that a union designed by the beneficiaries of state power will be allowed to work to any other advantage than that of the dominant political class.

\section{Conclusion}

It has been stated that there has been a consensus that the aim of the $\mathrm{AU}$ would be to consolidate the gains made by the OAU in its 37 years of existence and to advance the cause of collective action in African affairs. This paper however acknowledges that against the backdrop of the OAU's history and the general African condition, the new Union project fits into a prevailing condition which does not portend radical transformation due to internal and external constraints. New institutions and frameworks, themselves, will do little to rectify the situation described in the Yaounde Declaration of 1996 on Africa:

At the close of the $20^{\text {th }}$ century $\ldots$ of all the regions of the world, 
Africa is indeed the most backward in terms of development from whatever angle it is viewed, and the most vulnerable as far as security and stability are concerned.

Although this paper in conclusion would rather err on the side of hope than of despair, unity may not make Africa suddenly rich but it can make it difficult for Africa to be disregarded and humiliated. Perhaps marginalisation, so often decried, is what Africa needs right now. For one thing, it will help the evolution of an endogenous development agenda, an agenda that expresses the aspirations of the people and can therefore elicit their support. The AU may clearly be more than old wine in new bottles in the sense that it offers at least a new approach to Africa's collective efforts, but, given the continued existence of old political structures which will shape political will, the Union might well be new wine in an old bottle.

However, the fundamental issue is really not that of recounting the benefits but that of developing the political will among African statesmen and their readiness to bear the costs that is required to produce and sustain an effective union. This demands equitable burden-sharing in matters affecting the continent and the administration of the Union. It also requires an appropriate institutional framework with sufficient authority and capacity for implementing decisions. The creation of the necessary democratic environment rather than mere summit diplomatic rhetoric and the involvement of civil society in order to ensure the building of integrated production capacities are indispensable requirements for a solid union.

The success of the AU would require mature African statesmanship that strikes a balance between the desires of member states to pursue their individual interests, and the political will to forgo certain aspects of national sovereignty and independence for the common good of the continent. African states, marginalised by economic globalisation and under severe strains from poverty, war and other forms of degradation, cannot afford to be half-hearted in their pursuit of regional cooperation. Otherwise, it is difficult to see how they can survive on their own in a highly competitive global economy in the present world order. 


\section{Notes}

1. Claude Ake, Democracy and Development in Africa, Ibadan, Spectrum Books Ltd, 2001, p. 201.

2. See Anthoni Van Nieuwkerk, 'Regionalism into Globalism? War into Peace? SADC and ECOWAS Compared', African Security Review, Vol. 10 November 2, 2001, p. 7.

3. Ibid. p. 8 .

4. President Olusegun Obasanjo, 'African Union: The Challenges of Cooperation and Integration’, National Interest, June 11, 2001. p 6.

5. Ibid.

6. Claude Ake, Democracy and Development in Africa, Op cit. p. 201.

7. Ibid.

8. Read J. Baylis and S. Smith, The Globalization of World Politics. An Introduction to International Relations, New York, Oxford Press, 1997, pp. 409-425.

9. Ibid p. 40.

10. Ibid.

11. For a contemporary analysis of regionalism see A. Hurrell, 'Explaining the Resurgence of Regionalism in World Politics', in Review of International Studies, 21,4, 1995, cited in Baylis and Smith, The Globalization of World Politics op. cit. p. 410.

12. See Morten Boas, 'Regions and Rationalization: A Heretic's View', in Nordiska Afrikainstitutet, Regionalism and Regional Integration in Africa: A Debate of Current Aspects and Issues, Discussion Paper I, Uppsala, 2001, pp. 27-40.

13. Charles W. Kegley Jr. \& Eugene R. Wittkopt, World Politics, Trends and Transformation, New York, Martins Press, 1995, p. 539.

14. Ibid.

15. Ibid p. 540.

16. See Baylis and Smith, The Globalization of World Politics, op. cit p. 411.

17. Ibid.

18. Nordiska Afrikainstitutet, Regionalism and Regional Integration in Africa, op. cit. p. 38.

19. 'A History of Pan-Africanism', African Agenda, Vol 3, No. 4, 2000, pp. 29-31.

20. See Colin Legum, Pan-Africanism: A Short Political Guide, New York, Fredrick Praeger, 1962, pp. 45-47.

21. Ibid p. 48. 
22. See William Zartman, International Relations in the New Africa, Englewood Cliffs, New Jersey, Prentice Hall Inc, 1966, pp. 27-28.

23. Chris Brazier, 'African United: Not Hopeless nor Helpless', African Agenda, Vol. 3, No 4, pp. 11-15.

24. Ibid.

25. West African Magazine, July 12-18, 1993, p. 1197.

26. African Agenda, op. cit. p. 46.

27. Jackie Cilliers, 'Towards the African Union', African Security Review, vol. 10, No., 2, 2001, pp. 115-119.

28. 'Sule Lamido on Nigeria has no Reservation on African Union', ThisDay, (Lagos) April 8, 2001, p. 21.

29. Jackie Cilliers, 'From Acronym to Action: The Seminal Assembly of the African Union' in African Security Review, vol. II, No. 1, 2002,p. 97-102.

30. See Cameroon Duodu, 'Give Unity a Chance', News African Magazine, July 29, 2002, pp. 20- 21.

31. See Konstanz Mulikita, 'The UN Security Council and the OAU: Conflict or collaboration', African Security Review, vol. II, No 1, 2002, pp. 29-30.

32. Adams Oshiomole, 'Popular Participation and the African Union', in Adagbo Onoja (ed.), Plying the Foreign Pitch, vol. 2, 2000- 2001, Abuja: Ministry of Foreign Affairs, 2001, pp. 119-120.

33. Cilliers, 'Towards an African Union', op. cit p. 106.

34. Ibid.

35. Ibid.

36. Konstanz Mulikita, 'The Security Council and the OAU', op. cit p. 30 . 